Dept. of Food Hygiene,

Fac. of Vet. Med., Assiut Uni., Egypt.

\title{
INCIDENCE AND SURVIVAL OF ENTEROBACTER SAKAZAKII IN INFANTS POWDERED MILK-BASED FORMULAE USED BEFORE AND AFTER WEANING
}

(With 5 Tables and 5 Figures)

By

\section{A.A-H. AHMED; ENAS EL-PRINCE; EMAN KORASHY* and MARWA M.N. AL-GENDI*}

* Animal Health Research Institute, Assiut

(Received at 14/5/2008)

مدي تواجد ميكروب Enterobacter sakazakii في توليفات أغذية الأطفال الجافة المحتوية علي اللبن المستخدمة قبل وبعد الفطام

أحمد عبل الحمبل ، إيناس البرنس ، إيمان قرشي ، مروة الجندي

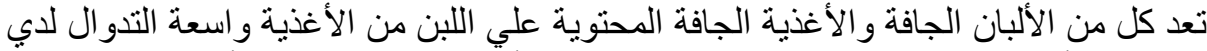

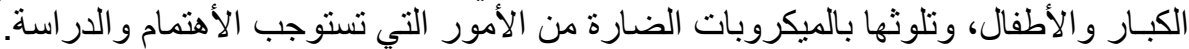

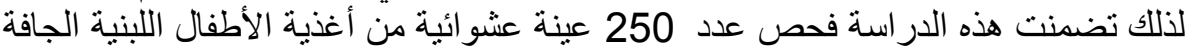

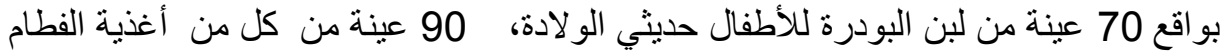

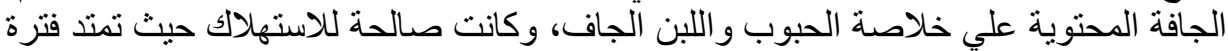

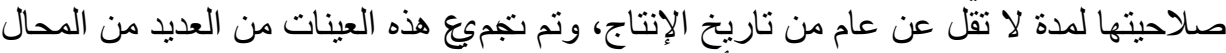

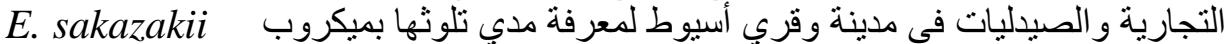

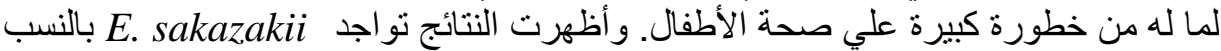

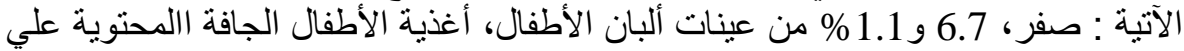

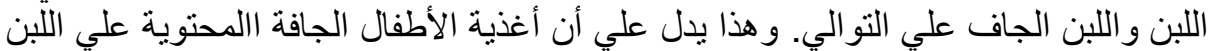

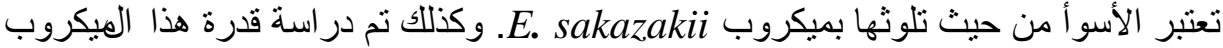

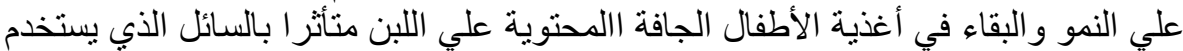

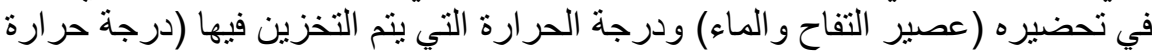

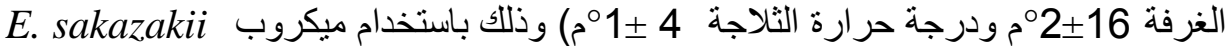

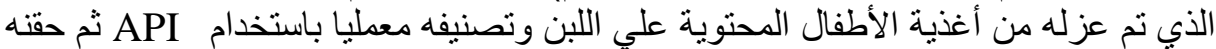

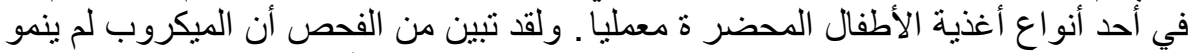

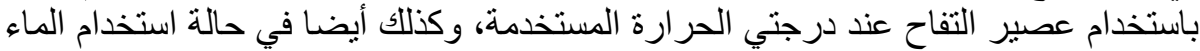

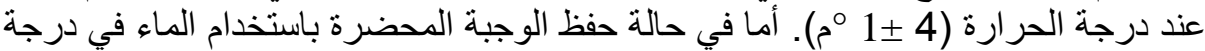

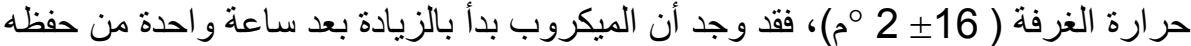

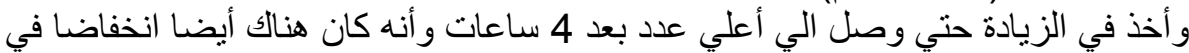

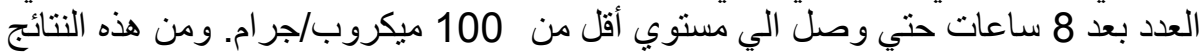


ينصح بعدم ترك الوجبة أكثر من ساعة في درجة حرارة الغرفة وحفظها في الثلاجة، كما

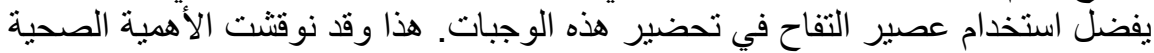
لميكروب E. sakazakii و الثروط الو اجب إتباعها لمنع تلوث ألبان و أغذية الأطفال المختلفة

\section{SUMMARY}

A total of two hundred and fifty random samples of infant's milk powder for babies after birth (70 samples), milk-based cereal weaning food (90 samples) and dried milk powder (90 samples) were purchased from different shops and pharmacies in Assiut city and villages around the city. The samples were still valid for consumption as shelf life is at least to be more than one year from production time and they were transferred to the laboratory in their packages to be examined for prevalence of Enterobacter sakazakii which could be isolated from 6/90 milk-based cereal baby food samples and from 1/90 dried milk powder samples, however, failed to be detected in infant milk formulae which considered as non sterile products. The survival and growth of E. sakazakii in milkbased cereal weaning food using different reconstituted liquids (apple juice and water) stored at different temperatures (room temperature $16 \pm 2{ }^{\circ} \mathrm{C}$ and refrigerated temperature $4 \pm 1^{\circ} \mathrm{C}$ ) were carried out. The results revealed that the growth did not occur in cereal reconstituted with apple juice, regardless of storage temperature, or in cereal reconstituted with water stored at $4 \pm 1^{\circ} \mathrm{C}$. Upon reaching maximum populations of 4 $\log 10 \mathrm{cfu} / \mathrm{g}$, in some instances populations decreased to nondetectable values during subsequent storage which was concurrent with decrease in $\mathrm{pH}$ values. E. sakazakii initially at very low populations can rapidly grow in infant cereal reconstituted with water. The public health hazards of E.sakazakii and the suggestive measures for improving the quality of infants' food were discussed.

Key words: E.sakazakii, Incidence, Survival, Infants milk powder, Milk-based cereal weaning food, Dried milk powder.

\section{INTRODUCTION}

Infants should be exclusively breast fed for the first 6 months of life and those, who are not, should be provided with a suitable breast milk substitute. The reconstitution of powdered infant formula (PIF) should be undertaken by caregivers using good hygienic measures and in accordance with the product manufacturer's food safety guidelines 
(Drudy et al., 2006). However, consumption of contaminated PIF has been epidemiologically linked with cases of infection. Contamination can occur during the manufacturing process or during post manufacture reconstitution of formula which is not a sterile product (Mullane et al., 2007). E. sakazakii is an opportunistic pathogen and the etiological agent in rare but life-threatening cases of meningitis, necrotizing enterocolitis, and sepsis in infants. Among infants, those at greatest risk are neonates ( $<28$ days), particularly those born prematurely or of low birth weight $(<2500 \mathrm{~g})$. It was recorded that infant mortality for E. sakazakii meningitis is 40-80\%, with death often occurring within hours of infection (Arseni et al., 1987). Although there is no epidemiological evidence for the amount of an infectious dose for E. sakazakii, it would seem reasonable to use a detection limit $<1$ cell in $25 \mathrm{~g}$ of infant food formula, equivalent to that of detection of Salmonellae in milk powder (Mansfield and Forsythe, 2000).

Moreover, there have been few reports recording E. sakazakii infection in adults, and it is not usually life threatening as they had serious underlying diseases, such as malignancies. However, E. sakazakii is a rare cause of invasive disease when meningitis occurs, severe neurological complications, including cerebral abscess formation, are common, and death occurs in 33-80\% of cases (Nazarowec-White and Farber, 1997a and Lai, 2001). The most frequently recorded method of entry of Enterobacter in patients with bacteremia was ingestion of contaminated foods or food ingredients like cereals, fruits and vegetables, legume products, herbs and spices as well as from animal food sources like milk, cheese, meat and fish and their products both raw and processed (Weischer and Kolmos, 1992 and Friedemann, 2007). It was hypothesized that the reservoir for $E$. sakazakii, in addition to other coliforms (Klebsiella oxytoca, K. pneumoniae, E. cloacae, and Citrobacter spp.) may be from primarily environmental and from plant materials (Mossel and Struijk, 1995).

Many authors could isolate E. sakazakii from infant milk formulae as Postupa and Aldová (1984); Simmons et al. (1989); Nazarowec-White and Farber (1997a); Nazarowec-White and Farber (1997c); Van Acker et al. (2001); MMWR (2002); Leuscher et al. (2004); Baiguini (2005); Jarvis (2005); Estuningsih et al. (2006); Iversen and Forsythe (2007); Shaker et al. (2007) and Torres-Chavolla et al. (2007). Moreover, Restaino et al. (2006), El-Prince et al. (2007) and Shaker et al. (2007) could isolate E. sakazakii from dried infant foods samples. Also, the survival and growth of E. sakazakii in infant cereals 
as affected by composition, reconstitution liquid, and storage temperature were measured by many investigators (Richards et al., 2005, Gurtler and Beuchat, 2007 and Lin and Beuchat, 2007).

As E. sakazakii was classified as a severe hazard for restricted populations, causing life-threatening or substantial chronic sequelae or illness of long duration (ICMSF, 2002), therefore, its incidence in infants powdered milk-based formulae used before and after weaning was studied. Also, its survival in cereals using different reconstitution liquids at various temperatures was investigated.

\section{MATERIALS and METHODS}

\section{Collection of samples:}

A total of two hundred and fifty random samples of infant's milk powder for babies after birth (70 samples), milk-based cereal weaning food and dried milk powder (90 samples each) were purchased from different shops and pharmacies in Assiut city and villages around the city. The samples were still valid for consumption as their shelf life is at least to be more than one year from the production time and they were transferred to the laboratory in their packages to be examined for the prevalence of E. sakazakii.

I- Isolation and identification of $\boldsymbol{E}$. sakazakii (FDA., 2002):

Each sample was aseptically opened and $10 \mathrm{~g}$ were weighed and homogenized in $90 \mathrm{ml}$ of sterile distilled water, shacked by hand until the powder was uniformly suspended, incubated overnight at $36^{\circ} \mathrm{C} .10 \mathrm{ml}$ of the incubated sample were transferred to $90 \mathrm{ml}$ of Enterobacteriaceae enrichment broth (EE) and incubated overnight at $36^{\circ} \mathrm{C}$. Loopfuls were streaked onto violet red bile agar (VRBL) and incubated overnight at $36^{\circ} \mathrm{C}$.

\section{Isolation procedures:}

From each VRBL plate, all colonies were purified on Tryptone Soy Agar (TSA). The TSA plates were incubated for 24 to $72 \mathrm{~h}$ in daylight at room temperature (about $25^{\circ} \mathrm{C}$ ). The yellow pigmentation on TSA is a characteristic feature of E. sakazakii.

\section{Identification of isolates:}

Isolates were identified using biochemical tests including Triple Sugar Iron (TSI), Urease test, Sugar fermentation tests, IMViC tests, catalase test then oxidase test. Oxidase-negative isolates were further identified using API 20E biochemical identification test system (bioMerieux SA, France). API 20E systems have been used for 
presumptive-positive confirmations of E. sakazakii via biochemical characteristics (Kandhai et al., 2004 b).

\section{II- Survival and growth of $E$. sakazakii in infant cereals using different reconstitution liquids at different storage temperatures.}

\section{Culture preparation:}

E. sakazakii strain used in the present study was previously isolated and identified from the examined dried milk-based baby foods. The organism was propagated in EE broth at $37^{\circ} \mathrm{C}$ for $24 \mathrm{~h}$. One $\mathrm{ml}$ of the culture was serially diluted in $0.1 \%$ peptone water to attain the desired inoculum level.

Preparation and inoculation of dried milk-based baby food samples:

Six portions of dried milk-based baby food obtained from Assiut markets, previously examined and found to be free from E. sakazakii, were reconstituted with sterile apple juice and sterile water as recommended by manufactures instructions $(50 \mathrm{~g}$ of dried milk-based baby food reconstituted with $150 \mathrm{ml}$ of reconstituted liquid). The prepared samples were inoculated with enough amount of broth culture to yield approximately $2 \times 10,2 \times 10^{2}$ and $2 \times 10^{3} \mathrm{cfu} / \mathrm{ml}$ of E. sakazakii and control samples were prepared for each treatment, without addition of the organism. Each sample was divided into 2 equal portions, one was stored at room temperature $\left(16 \pm 2^{\circ} \mathrm{C}\right)$ and the other at refrigeration temperature $\left(4 \pm 1^{\circ} \mathrm{C}\right)$ with their control.

Preparation of dried milk-based baby food samples for examination:

Samples were prepared following the procedures described by American Public Health Association (A.P.H.A., 1992).

Enumeration of $E$. sakazakii in the inoculated samples:

From the inoculated samples and their control, 10 fold serial dilutions were prepared using $0.1 \%$ peptone water for determination of E. sakazakii count, using direct spreading method. Duplicate TSA plates were inoculated with each dilution by spreading $0.1 \mathrm{ml}$ evenly onto the surface of each plate with a sterile glass spreading rod. Inoculated plates were incubated at $30^{\circ} \mathrm{C}$ for $48-72 \mathrm{~h}$. The $\mathrm{cfu} / \mathrm{g}$ was calculated and recorded. Samples and their control stored at room temperature $\left(16 \pm 2^{\circ} \mathrm{C}\right)$ were examined for E. sakazakii at $0,1,4,8$ and $12 \mathrm{~h}$, while those stored at refrigerating temperature $\left(4 \pm 1^{\circ} \mathrm{C}\right)$ were tested every 2,4 , 812 and $48 \mathrm{~h}$. 


\section{RESULTS}

The obtained results are recorded in Tables 1-5 and Figures 1-5

Table 1: Incidence of E. sakazakii in the examined samples of powdered milk-based formulae.

\begin{tabular}{|c|c|c|c|}
\hline \multirow{2}{*}{ Type of samples } & \multirow{2}{*}{ No. of examined samples } & \multicolumn{2}{|c|}{ Positive samples } \\
\cline { 3 - 4 } & & No. & $\%$ \\
\hline Infant milk formulae & 70 & - & - \\
\hline Milk-based cereal weaning food & 90 & 6 & $6.7 \%$ \\
\hline Dried milk powder & 90 & 1 & $1.1 \%$ \\
\hline
\end{tabular}

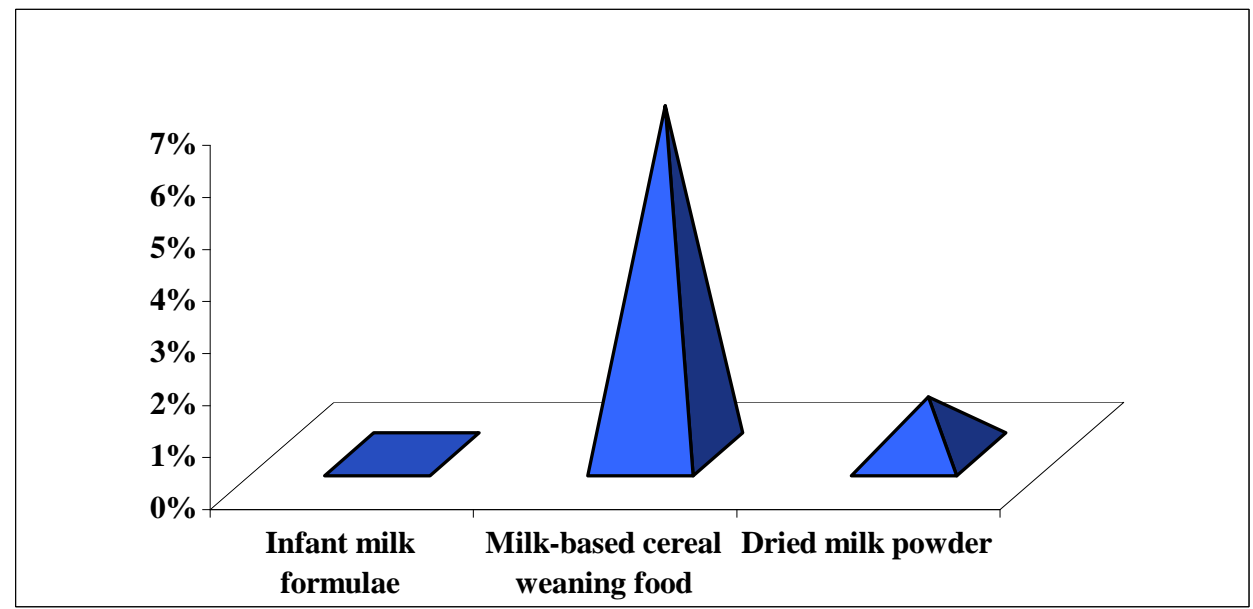

Fig. 1: Incidence of E. sakazakii in the examined samples of powdered milk-based formulae.

Table 2: Survival of E. sakazakii in infant cereal milk-based food using water as reconstitution liquid and stored at room temperature $\left(16 \pm 2{ }^{\circ} \mathrm{C}\right)$.

\begin{tabular}{|c|c|c|c|}
\hline Storage time & Inoculum $1 / \mathrm{g}$ & Inoculum $2 / \mathrm{g}$ & Inoculum 3/g \\
\hline 0 & $3 \times 10$ & $3 \times 10^{2}$ & $2 \times 10^{3}$ \\
$1 \mathrm{~h}$ & $1 \times 10^{2}$ & $4 \times 10^{2}$ & $3 \times 10^{3}$ \\
$4 \mathrm{~h}$ & $3 \times 10^{4}$ & $1 \times 10^{3}$ & $4 \times 10^{3}$ \\
$8 \mathrm{~h}$ & $1 \times 10^{2}$ & $8 \times 10^{2}$ & $6 \times 10^{2}$ \\
$12 \mathrm{~h}$ & $*<100$ & $*<100$ & $*<100$ \\
\hline
\end{tabular}

* Not detected on the plate $(<100)$, but the organisms could be isolated from the examined samples. 


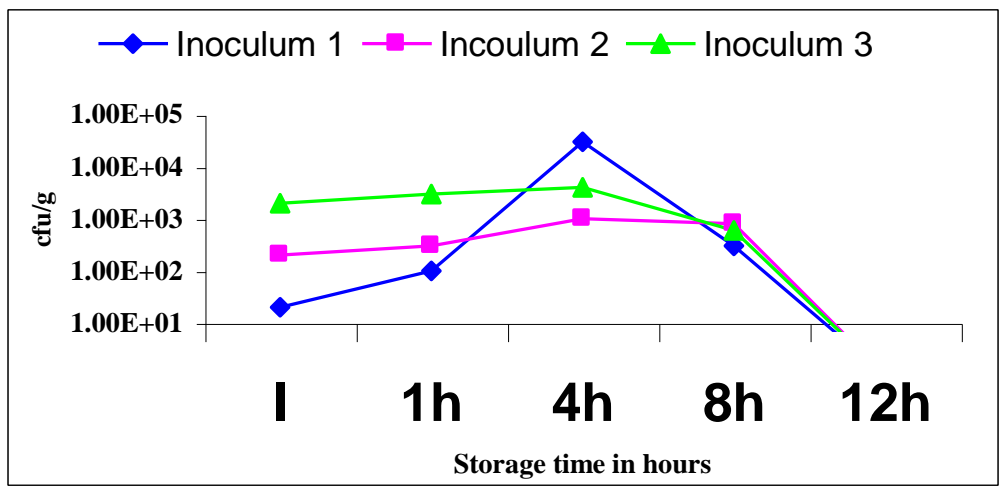

Fig. 2: Survival of E. sakazakii in infant cereal milk-based food using water as reconstitution liquid and stored at room temperature $\left(16 \pm 2{ }^{\circ} \mathrm{C}\right)$.

Table 3: Survival of E. sakazakii in infant cereal milk-based food using apple juice as reconstitution liquid and stored at room temperature $\left(16 \pm 2{ }^{\circ} \mathrm{C}\right)$.

\begin{tabular}{|c|c|c|c|}
\hline Storage time & Inoculum $1 / \mathrm{g}$ & Inoculum $2 / \mathrm{g}$ & Inoculum $3 / \mathrm{g}$ \\
\hline 0 & $3 \times 10$ & $3 \times 10^{2}$ & $2 \times 10^{3}$ \\
$1 \mathrm{~h}$ & $*<100$ & $*<100$ & $*<100$ \\
$4 \mathrm{~h}$ & $*<100$ & $*<100$ & $*<100$ \\
$8 \mathrm{~h}$ & $*<100$ & $*<100$ & $*<100$ \\
$12 \mathrm{~h}$ & $\mathrm{ND}$ & $\mathrm{ND}$ & $\mathrm{ND}$ \\
\hline
\end{tabular}

* Not detected on the plate $(<100)$ but could be isolated. ND $=$ E. sakazakii could not be isolated in 1, 10 and $25 \mathrm{~g}$ of infant cereal milk-based food.

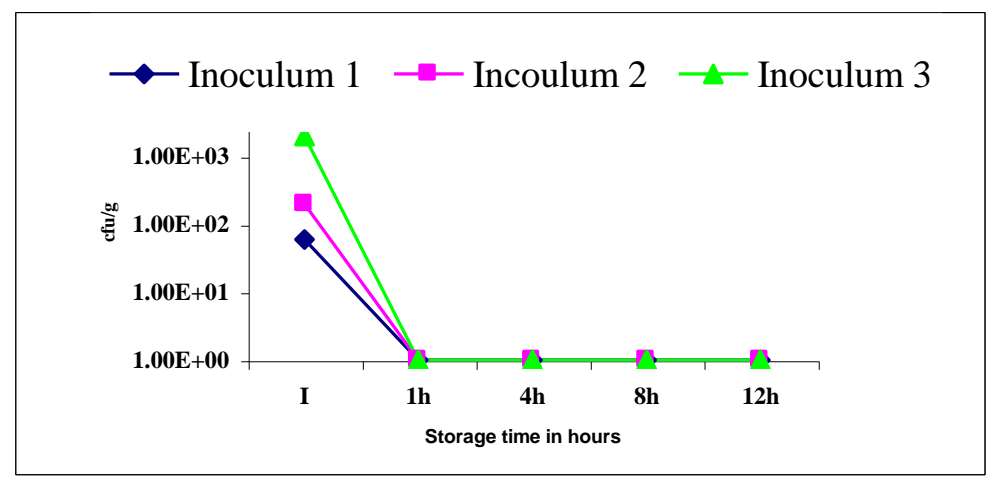

Fig. 3: Survival of E. sakazakii in infant cereal milk-based food using apple juice as reconstitution liquid and stored at room temperature $\left(16 \pm 2{ }^{\circ} \mathrm{C}\right)$. 
Table 4: Survival of E. sakazakii in infant cereal milk-based food water as reconstitution liquid and stored at refrigerated temperature $\left(4 \pm 1^{\circ} \mathrm{C}\right)$.

\begin{tabular}{|c|c|c|c|}
\hline Storage time & Inoculum $1 / \mathrm{g}$ & Inoculum $2 / \mathrm{g}$ & Inoculum $3 / \mathrm{g}$ \\
\hline 0 & $3 \times 10$ & $3 \times 10^{2}$ & $2 \times 10^{3}$ \\
$1 \mathrm{~h}$ & $*<100$ & $*<100$ & $*<100$ \\
$4 \mathrm{~h}$ & $*<100$ & $*<100$ & $*<100$ \\
$8 \mathrm{~h}$ & $*<100$ & $*<100$ & $*<100$ \\
$12 \mathrm{~h}$ & $\mathrm{ND}$ & $\mathrm{ND}$ & $\mathrm{ND}$ \\
\hline
\end{tabular}

* Not detected on the plate ( count $<100$ ) but the organisms could be isolated.

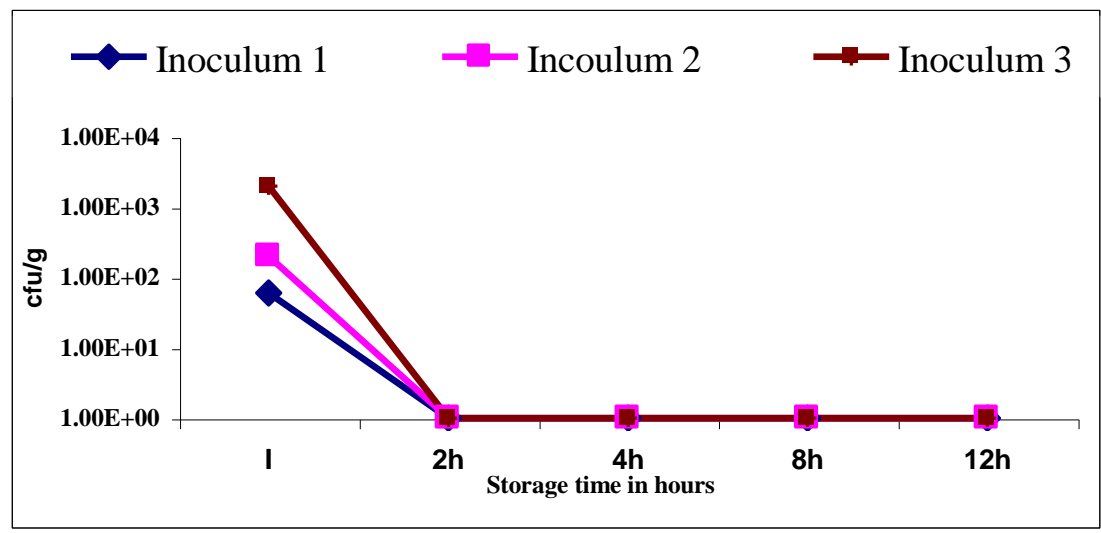

Fig. 4: Survival of E. sakazakii in infant cereal milk-based food using water as reconstitution liquid and stored at refrigerated temperature $\left(4 \pm 1^{\circ} \mathrm{C}\right)$.

Table 5: Survival of E. sakazakii in infant cereal milk-based food apple juice as reconstitution liquid and stored at refrigerated temperature $\left(4 \pm 1^{\circ} \mathrm{C}\right)$.

\begin{tabular}{|c|c|c|c|}
\hline Storage time & Inoculum $1 / \mathrm{g}$ & Inoculum $2 / \mathrm{g}$ & Inoculum $3 / \mathrm{g}$ \\
\hline 0 & $3 \times 10$ & $3 \times 10^{2}$ & $2 \times 10^{3}$ \\
$1 \mathrm{~h}$ & $*<100$ & $*<100$ & $*<100$ \\
$4 \mathrm{~h}$ & $*<100$ & $*<100$ & $*<100$ \\
$8 \mathrm{~h}$ & $*<100$ & $*<100$ & $*<100$ \\
$12 \mathrm{~h}$ & $*<100$ & $*<100$ & $*<100$ \\
\hline
\end{tabular}

* Could not be detected on the plate (count < 100) but the organisms could be isolated. $\mathrm{ND}=$ E. sakazakii could not be isolated in 1, 10 and $25 \mathrm{~g}$ of infant cereal milk-based food. 


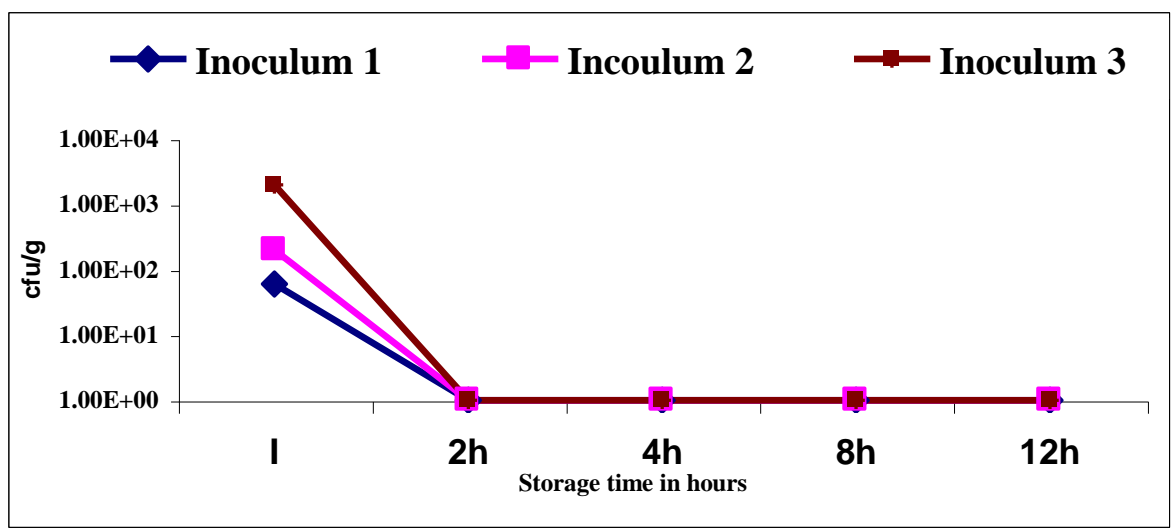

Fig. 5: Survival of E. sakazakii in infant cereal milk-based food using apple juice as reconstitution liquid and stored at refrigerated temperature $\left(4 \pm 1^{\circ} \mathrm{C}\right)$.

\section{DISCUSSION}

The results achieved in Table 1 \& Fig. 1, indicated that IMF samples were found to be free from E. sakazakii. However, many investigators could isolate E. sakazakii from IMF as Postupa and Aldová (1984); Simmons et al. (1989); Nazarowec-White and Farber (1997a); Nazarowec-White and Farber (1997c); Van Acker et al. (2001); MMWR (2002); Leuscher et al. (2004); Baiguini (2005); Jarvis (2005); Estuningsih et al. (2006); Iversen and Forsythe (2007) and Shaker et al. (2007). Moreover, higher incidence of E. sakazakii could be detected by Torres-Chavolla et al. (2007). Also, E. sakazakii could be isolated from $6(6.7 \%)$ of the examined milk-based cereal weaning food samples. Somewhat similar percentage was obtained by El-Prince et al. (2007) who could isolate E. sakazakii from 1 out of 30 (3.33\%), of examined dried infant foods samples. While, higher percentages were detected by Restaino et al. (2006) and Shaker et al. (2007). Moreover, 1 strain $(1.1 \%)$ of E. sakazakii was recovered from the examined samples of dried milk powder, however it failed to be detected as postulated by El-Prince et al. (2007) and Shaker et al. (2007). While, slightly higher percentage was estimated by Postupa and Aldová (1984) who could isolate 4 strains of E. sakazakii from milk powder in Czechoslovakia. Nazarowec-White and Farber (1997b) stated that microbial pathogens could gain access to the milk powder from the environment or from the addition of ingredients at the powder stage. 
According to Commission Regulation (EC) (2005) on the microbiological criteria for foodstuffs, E. sakazakii is considered a microorganism of greatest concern in infant formulae and follow-on formulae. E. sakazakii is included between "safety criteria" and it must be absent in $10 \mathrm{~g}$ of dried infant formulae and dried dietary foods for special medical purposes intended for infants below 6 months of age (Conte and Passantino, 2007). The infectious dose can vary according to the organism's history (stress response factors), host state (healthy or immunocompromised) and food matrix. Several physiological characteristics of E. sakazakii appear to play an important role in this transmission route: (i) it can grow in a broad range of temperatures of 6-45 ${ }^{\circ} \mathrm{C}$ (Iversen et al., 2004 a); (ii) it can survive longer than other Enterobacteriaceae under conditions of dry or osmotic stress, which might provide a selection pressure in dried milk products (Breeuwer et al., 2003); (iii) it can efficiently form biofilms on various materials, including the frequently used polycarbonate material from infant-feeding bottles (Iversen et al., 2004 b and Lehner and Stephan, 2004); (iv) in reconstituted infant formula, E. sakazakii seems to be more heatresistant than other species of Enterobacteriaceae (Nazarowec-White and Farber, 1997 b).

Hygiene mismanagement due to incorrect temperature and time factors as well as due to the contact transmission of microorganisms via hands, insects, small vertebrates and equipment should be avoided during production, preparation and storage of food and drink. E. sakazakii may be associated with food spoilage, but, the detection of the ubiquitous E. sakazakii in food is not always an indicator for hygiene mismanagement.

It is obvious from the aforementioned results that milk-based cereal weaning food samples were the highest in contamination with E. sakazakii. Its presence in the examined samples probably originated from factories producing milk powder, cereals, chocolate, potato flour and pasta as well as in households strongly indicates that the organisms are widespread. Also, the high tolerance of E. sakazakii to desiccation provides a competitive advantage in dry environments thereby increases the risk of post-pasteurization contamination of the finished product (Breeuwer et al., 2003 and Kandhai et al., 2004 a).

The survival of E. sakazakii in infant cereal milk-based food using water as reconstitution liquid and stored at room temperature $\left(16 \pm 2{ }^{\circ} \mathrm{C}\right)$ was recorded in Table $2 \&$ Fig.2. It is evident by using 3 different inoculums $\left(3 \times 10,3 \times 10^{2}\right.$ and $\left.2 \times 10^{3}\right)$ that, the numbers of 
E. sakazakii increased to $1 \times 10^{2}, 4 \times 10^{2}$ and $3 \times 10^{3} \mathrm{cfu} / \mathrm{g}$ after $1 \mathrm{~h}$ of inoculation and reach the peak after 4 h to be $3 \times 10^{4}, 1 \times 10^{3}$ and $4 \times 10^{3}$ $\mathrm{cfu} / \mathrm{g}$, respectively. The organisms began to decline rapidly after $8 \mathrm{~h}$ to reach $1 \times 10^{2}, 8 \times 10^{2}, 6 \times 10^{2} \mathrm{cfu} / \mathrm{g}$, respectively, then reached to undetectable numbers after $12 \mathrm{~h}$ of storage $(<100 / \mathrm{g})$. However, it was detected by enrichment of one $g$ of each treatment. From the previous results, it is clear that E. sakazakii initially at very low populations can rapidly grow in infant cereal reconstituted with water. These results are harmony with those obtained by Richards et al. (2005), Gurtler and Beuchat (2007) and Lin and Beuchat (2007).

From the data recorded in Table $3 \&$ Fig. 3, it is apparent that E. sakazakii failed to be counted $(<100)$ in the 3 different inoculated samples after one hour of inoculation when apple juice was used as a reconstituted liquid stored at room temperature $\left(16 \pm 2{ }^{\circ} \mathrm{C}\right)$. After $12 \mathrm{~h}, E$. sakazakii could not be isolated from 1, 10, $25 \mathrm{~g}$ of examined samples using $\mathrm{E}$ E broth. Absence of E. sakazakii in examined samples reconstituted with apple juice coincided with decreases in $\mathrm{pH}$ and an increase in the population of lactic acid bacteria. These results go parallel with the findings obtained by Weir (2002), Richards et al. (2005) and Lin and Beuchat (2007).

On the other hand, E.sakazakii did not grow in infant cereal milk-based food reconstituted either with water or apple juice and stored at $4 \pm 1{ }^{\circ}$ C. E.sakazakii failed to be detectable in both water and apple juice reconstituted samples after $2 \mathrm{~h}$ of storage and thereafter. However, the organisms could be isolated by enrichment procedures from water reconstituted samples after 4,8 and $12 \mathrm{~h}$ and failed to be isolated from 1 , 10 and $25 \mathrm{~g}$ after $12 \mathrm{~h}$ of storage in apple juice reconstituted samples (Tables $4 \& 5$ and Fig. $4 \& 5$ ). Our results were in accordance with those obtained by Farmer et al. (1980), Iversen et al. (2004 b), Richards et al. (2005), Gurtler and Beuchat (2007) and Lin and Beuchat (2007).

E.sakazakii is a pathogen of great concern to food industry, especially in foods normally stored under refrigeration conditions, unlike most food borne pathogens; it is able to multiply at refrigerator temperature $\left(6^{\circ} \mathrm{C}\right)$. These findings confirm the importance of proper refrigeration, consequently, refrigeration should not be relied upon as the sole method for control of E. sakazakii, but should be incorporated with other means of preservation. Simmons et al. (1989) recommended the using of refrigeration and limiting the hang time to prevent or retard the growth of E. sakazakii. Nazarowec-White and Farber (1997a) found that E. sakazakii did not grow at $4^{\circ} \mathrm{C}$ and began to die off during storage at 
this temperature and warned improper preparation and storage of reconstituted dried infant formulae at ambient temperature. Moreover, trained personnel should prepare dried milk-based products under aseptic techniques and conditions in a designated area following the manufacturer's instructions. The composition of infant cereals did not markedly affect the survival or growth of E. sakazakii in reconstituted cereals (Lin and Beuchat, 2007).

It is clear from the present study that reconstituted infant cereal can support luxuriant growth of E. sakazakii and when it is not immediately consumed should be discarded or stored at a temperature at which it cannot grow for only $24 \mathrm{~h}$. Also, the reconstituted infant cereals stored at $30^{\circ} \mathrm{C}$ should be discarded within $1 \mathrm{~h}$ after preparation.

\section{REFERENCES}

A.P.H.A. (1992): Standard Methods for the Examination of Dairy Products. 13th Ed., American Public Health Association.

Arseni, A.; Malamou-Ladas, E.; Koutsia, C.; Xanthou, M. and Trikka, E. (1987): Outbreak of colonization on neonates with E.sakazakii. J. Hosp. Infect., 9: 143-150.

Baiguini, A. (2005): E. sakazakii: an emerging pathogen!. Pediater. Med. Chir., 27 (1-2): 98-100.

Breeuwer, P.; Lardeau, A.; Peterz, M. and Joosten, H.M. (2003): Desiccation and heat tolerance of E. sakazakii. J. Appl. Microbiol., 95: 967-973.

Commission Regulation (EC) (2005): Microbiological criteria for foodstuffs No. 2073/2005, Official J., L 338, pp. :1-26.

Conte, F. and Passantino, A. (2007): Isolation of E. sakazakii from ass' milk in Sicily. Case report, safety and legal issues. Travel Med. Infect. Disease, 5 (6): 413.

Drudy, N.R.; Mullane, T.; Quinn, P.; Wall, G. and Fanning, S. (2006):

E. sakazakii: An emerging pathogen in powdered infant formula. Clinical Infect. Diseases, 42: 996-1002.

El-Prince, Enas; Sayed, M. and Abdel-Haleem, Amal, A. (2007): Incidence and public health hazard of E. sakazakii in milk powder and some dried milk-based foods. Assiut Vet. Med. J., 53 (113): 124-137.

Estuningsih, S.; Kress, C.; Hassan, A.A.; Akineden, O.; Schneider, E. and Usleber, E. (2006): Enterobacteriaceae in dehydrated 
powdered infant formula manufactured in Indonesia and Malaysia. J. Food Prot., 69 (12): 3013-3017.

Farmer, J.J.; Asbury, M.A.; Hickman, F.W.; Brenner, D.J. and the Enterobacteriaceae Study Group (1980): E. sakazakii, new species of Enterobacteriaceae isolated from clinical specimens. Int. J. Syst. Bacteriol., 30: 569-584.

FDA (Food and Drug Administration), Center for Food Safety and Applied Nutrition (2002): Isolation and enumeration of E. sakazakii from dehydrated powdered infant formula. Available at http://www.cfsan.fda.gov/ comm/mmesakaz.html.

Friedemann, Miriam (2007): E. sakazakii in food and beverages (other than infant formula and milk powder). Int. J. Food Microbiol., 116 (1): 1-10.

Gurtler, J.B. and Beuchat, L.R. (2007): Growth of E. sakazakii in reconstituted infant formula as affected by composition and temperature. J. Food Prot., 70 (9): 2095-2103.

ICMSF (International Commission on Microbiological Specifications for Foods) (2002): Microorganisms in Foods. Microbiological Testing in Food Safety Management. Vol. 7. Chap. 8. Selection of Cases and Attribute Plans, Kluwer Academic/Plenum Publ., New York.

Iversen, C. and Forsythe, S.J. (2007): Comparison of media for the isolation of E. sakazakii. Appl. Environ. Microbiol., 73 (1): 48-52.

Iversen, C.; Druggan, P. and Forsythe, S.J. (2004 a): C.A selective differential medium for E. sakazakii. Int. J. Food Microbiol., 96: 133-139.

Iversen, C.; Lane, M. and Forsythe, S.J. (2004 b): The growth profile, thermo tolerance and biofilm formation of E. sakazakii grown in infant formula milk. Letters in Appl. Microbiol., 38: 378-382.

Jarvis, C. (2005): Fatal E. sakazakii infection associated with powdered infant formula in a neonatal intensive care unit in New Zealand New Investigator Award, Blue Ribbon Abstract Award: American J. Infection Control, 33 (5): e19.

Kandhai, M.C.; Reij, M.W.; Gorris, L.G.M. and Zwietering, M.H. (2004a): The effect of pre-culturing conditions on the lag time and growth rate of E. sakazakii. Book of Abstracts, 19th Int. Symp., Int. Com. Food Microbiol. Hyg., Portoroz, Slovenia, p. 335. 
Kandhai, M.C.; Reij, M.W.; Van Puyveld, K.; Guillaume-Gentil, O.; Beumer, R.R. and Van Schothorst, M. (2004 b): A new protocol for the detection of E. sakazakii applied to environmental samples. J. Food Prot., 67: 1267-1270.

Lai, K.K. (2001): E. sakazakii infections among neonates, infants, children, and adults. Medicine, 80: 113-122.

Lehner, A. and Stephan, R. (2004): Microbiological, epidemiological, and food safety aspects of E. sakazakii. J. Food Prot., 67: (12): 2850-2857.

Leuscher, R.G.K.; Baird, F.; Donald, B. and Cox, L.J. (2004): A medium for the presumptive detection of E. sakazakii in infant formula. Food Microbiol., 21:527-533.

Lin, L.C. and Beuchat, L.R. (2007): Survival and growth of E. sakazakii in infant cereal as affected by composition, reconstitution liquid, and storage temperature. J. Food Prot., 70 (6):14101422.

Mansfield, L.P. and Forsythe, S.J. (2000): Detection of Salmonellae in food. Reviews in Medical Microbiol., 11: 37-46.

MMWR (Morbidity and Mortality Weekly Reports) (2002): April 12, 2002/51(14):298-300.

Mossel, D.A.A. and Struijk, C.B. (1995): E. coli, otras Enterobacteriaceae indicadores adicionales como marcadores de la calidad microbiologica de los alimentos, Microbiologia SEM., 11: 75-90.

Mullane, N.R.; Whyte, P.; Wall, P.G.; Quinn, T. and Fanning, S. (2007): Application of pulsed-field gel electrophoresis to characterize and trace the prevalence of E. sakazakii in an infant formula processing facility. Int. J. Food Microbiol., 116(1): 73-81.

Nazarowec-White, M. and Farber, J.J. (1997 a): Thermal resistance of E. sakazakii in reconstituted dried-infant formula. Letters in Appl. Microbiol., 24: 9-13.

Nazarowec-White, M. and Farber, J.J. (1997 b): E. sakazakii: A review. Int. J. Food Microbiol., 34: 103-113.

Nazarowec-White, M. and Farber, J.J. (1997 c): Incidence, survival, and growth of E. sakazakii in infant formula. J. Food Prot., 60: 226-233.

Postupa, R. and Aldová, E. (1984): E. sakazakii: A Tween 80 esterasepositive representative of the genus Enterobacter isolated from powdered milk specimens. J. Hyg. Epidemiol. Microbiol., 28: 435-440. 
Restaino, L.; Frampton, E.W.; Lionberg, W.C. and Becker, A.R.J. (2006): Chromogenic plating medium for the isolation and identification of E. sakazakii from foods, food ingredients, and environmental sources. J. Food Prot., 69: 315-322.

Richards, G.M.; Gurtler, J.B. and Beuchat, L.R. (2005): Survival and growth of $E$. sakazakii in infant rice cereal reconstituted with water, milk, liquid infant formula, or apple juice. J. Appl. Microbiol., 99(4):844-850.

Shaker, R.; Tareq, O.; Wail, A.; Ziad, J. and Mahmoud, A. (2007): Isolation of E. sakazakii and other Enterobacter spp. from food and food production environments. Food Control, 18 (10): 1241-1245.

Simmons, B.P.; Gelfand, M.S.; Haas, M.; Metts, L. and Ferguson, J. (1989): E. sakazakii infections in neonates associated with intrinsic contamination of a powdered infant formula. Infect. Control Hosp. Epidemiol., 10:398-401.

Torres-Chavolla, E.; Ramírez-Cerda, E. and Gutiérrez-Rojo, R. (2007): Isolation and identification of $E$. sakazakii in infant milk formulas. Food borne Pathog. Dis., 4(2):164-168.

Van Acker, J.; De Smet, F.; Muyldermans, G.; Bougatef, A.; Naessens, A. and Lauwers, S. (2001): Outbreak of necrotizing enterocolitis associated with E. sakazakii in powdered milk formula. J. Clin. Microbiol., 39:293-297.

Weir, E. (2002): Powdered infant formula and fatal infection with E. sakazakii. Can. Med. A.

Weischer, M. and Kolmos, H.J. (1992): Reprospective 6-year study Enterobacter bacteraemia in a Danish university hospital. J. Hosp. Infec., 20: 15-24. 